\title{
Experimental design and modeling of removal of Acid Green 25 dye by nanoscale zero-valent iron
}

\author{
Siroos Shojaei $^{1}$ (1) $\cdot$ Saeed Shojaei ${ }^{2}$
}

Received: 26 March 2017 / Accepted: 29 June 2017/Published online: 18 July 2017

(C) Springer International Publishing AG 2017

\begin{abstract}
We have used nanoscale zero-valent iron particles to remove Acid Green 25 (AG-25) dye from aqueous solution and have studied the effects of important variables, such as dye concentration, catalyst amount, $\mathrm{pH}$ and time, on the dye removal process, optimized by the Taguchi approach. Sixteen experiments were required to study the effect of all four parameters on removal of the dye. Each experiment was repeated three times to calculate the signal/ noise $(\mathrm{S} / \mathrm{N})$ ratio. Based on the $\mathrm{S} / \mathrm{N}$ ratio, optimum values of $4,0.6 \mathrm{~g}, 120 \mathrm{~s}, 20 \mathrm{mg} \mathrm{L}^{-1}$ were obtained for $\mathrm{pH}$, catalyst amount, time and dye concentration, respectively. At the optimized condition, the removal percentages of AG-25 dye was found to be $96.82 \%$.
\end{abstract}

Keywords Modeling · Optimization · Zero-valent iron nanoparticle . Taguchi method Environmental effects . AG-25 dye

\section{Introduction}

Colors are considered to be important pollutants in sewage because they create undesirable effects, may interfere with antibacterial growth and prevent the photosynthesis of aquatic plants and also increase the chemical oxygen demand (COD) of the water (Solache-Ríos et al. 2010).

Siroos Shojaei

shojaeisiroos@gmail.com

1 Department of Chemistry, University of Sistan and Baluchestan, Zahedan, Iran

2 Department of Management the Arid and Desert Regions, College of Natural Resources and Desert, Yazd University, Yazd, Iran
The inherent toxicity of some colors has deleterious effects on fishes and microorganisms and may even cause their death, while other colors may lead to eczema and cancer in humans (Mahanta et al. 2008; Verma and Banik 2013). Various industries are important sources of environmental pollution, and the effluents of these industries are, in most countries, emptied into the natural water system without any refinement or modification. Dyeing/textile industries produce vast amounts of effluents of which the main component is colors (Prado et al. 2008). Due to various combinations, Processing of the sewage from such factories and production centers is complicated due to the various combinations of components in the sewage. The textile industry is an economically important industry, and polluted water resources and colors used in these industries find their way through the sewers into the environment (Lewis 2014; Akcil et al. 2015). For this reason, the reduction and elimination of all types of dyes from industrial effluents are of considerable importance, and the dumping of color effluents into water resources is prohibited. There are various methods to remove dyes from sewage, such as adsorption, biodegradation, coagulation, filtration and reverse osmosis (Han et al. 2010; Yu et al. 2010). Surface adsorption is considered to be an efficient process among color removal methods due to its low cost, ease of operation and high efficiency (Alpat et al. 2008; Gök et al. 2010).

In past studies, researchers mostly studied one factor at any one time, which was a tedious and time-consuming approach. The design of any experiment can be considered to be an instrument of analysis for modeling and analyzing the effects of control agents as response variables. The traditional design of experiments on colors was problematic, particularly when the number of agents and the number of experiments were too large. The Taguchi design 
is a method used as an experimental technique to reduce the number of experiments using orthogonal arrays (Nalbant et al. 2007). In recent years, the use of nanoscale zerovalent iron (NZVI) particles has received broad scientific acceptance due to its high decolorization power and toxicity reduction capacity (Bigg and Judd 2000; Shojaei et al. 2017). In the study reported here, Acid Green 25 (AG-25) dye removal by NZVI particles was studied. The effect of time, $\mathrm{pH}$, dye concentration and the catalyst amount were examined. The Taguchi method was used to optimize the process of AG-25 dye removal.

\section{Experimental}

\section{Material and instrumentation}

The materials used in this study include ferric chloride $\left(\mathrm{FeCl}_{3} \cdot 6 \mathrm{H}_{2} \mathrm{O}\right)$, sodium borohydride $\left(\mathrm{NaBH}_{4}\right)$, acetone $\left.\mathrm{C}_{3} \mathrm{H}_{6} \mathrm{O}\right)$, hydrochloric acid $(\mathrm{HCl})$ and sodium hydroxide $(\mathrm{NaOH})$ (all obtained from Merck KGaA, Darmstadt, Germany). AG-25 dye with laboratory purity level was prepared for use as the chromogenic material. The general specifications of the AG-25 dye are presented in Table 1. The stock solution (1000 $\mathrm{mg} \mathrm{L}^{-1}$ ) was made from AG-25 dye, and double distilled water was used to dilute the dye solution to the desired volume. The solutions of $\mathrm{HCl}$ $(0.1 \mathrm{M})$ and $\mathrm{NaOH}(0.1 \mathrm{M})$ were used to adjust the $\mathrm{pH}$, and a $\mathrm{pH}$ meter was used to measure the $\mathrm{pH}$. Qualitek-4 software was used to analyze the data. The morphology and size of the particles were observed by scanning electron microscopy (SEM). The crystal structure of the product was examined by X-ray diffraction (XRD) with $\mathrm{Cu} \mathrm{K} \alpha$ radiation.

\section{Preparation of NZVI particles}

Nanoscale zero-valent iron particles were prepared by the liquid phase reduction method (Glavee et al. 1995).
Sodium borohydride solution $(0.3 \mathrm{M})$ was added dropwise into an equal volume of ferric chloride solution $(0.1 \mathrm{M})$ during vigorously stirring under a $\mathrm{N}_{2}$ atmosphere. The reaction can be described by the following equation (Sun et al. 2006):

$$
\begin{aligned}
4 \mathrm{Fe}^{3+}+3 \mathrm{BH}_{4}^{-}+9 \mathrm{H}_{2} \mathrm{O} \rightarrow & 4 \mathrm{Fe}^{0}+3 \mathrm{H}_{2} \mathrm{BO}_{3}^{-}+12 \mathrm{H}^{+} \\
& +6 \mathrm{H}_{2} .
\end{aligned}
$$

Following the reaction, the solid was vacuum-filtered and washed with double-distilled water and acetone. The resulting black solid was allowed to stand for $30 \mathrm{~min}$ in a $\mathrm{N}_{2}$ atmosphere before use.

\section{Taguchi design}

In this study, the $\mathrm{L}_{16}$ model of the Taguchi method of experimental design was used to determine the optimal conditions for dye removal. The $\mathrm{L}_{16}$ model has four columns and 16 rows, with each column belonging to an agent and each row belonging to an experiment. For example, the first column shows the catalyst amount at the first level for the first four experiments and at the second level for the second four experiments. In the $\mathrm{L}_{16}$ model, each variable is examined at four levels. In other words, it is recommended that 16 experiments be used to investigate four variables at four levels. Given all of the possible combinations among the four factors, $4^{4}=256$ experiments are necessary to cover all possible states; of these 256 experiments, the 16 experiments which have the greatest influence on four relevant variables are recognized and recommended in the Taguchi method using statistical methods (Taguchi et al. 2000; Roy 2001). These factors are pH, catalyst amount, dye concentration and time, whose values are given in Table 2.

The Taguchi method uses the signal/noise $(\mathrm{S} / \mathrm{N})$ ratio of the deviation of characteristic with the desired value. S/N ratios are different for each type of characteristic, and the larger the amount of characteristics, the better. The unit of
Table 1 General characteristics of Acid Green 25 dye

\begin{tabular}{lll}
\hline Characteristic & Description \\
\hline Color index name & Acid Green $25(\mathrm{AG}-25)$ \\
Molecular formula & $\mathrm{C}_{28} \mathrm{H}_{20} \mathrm{~N}_{2} \mathrm{Na}_{2} \mathrm{O}_{8} \mathrm{~S}_{2}$ \\
Molecular weight & $622.58 \mathrm{~g} \mathrm{~mol}^{-1}$ \\
$\lambda_{\max }$ & $643 \mathrm{~nm}$ &
\end{tabular}


Table 2 Levels and variables used for removal of the Acid Green 25 dye

\begin{tabular}{lllll}
\hline Variables & \multicolumn{2}{l}{ Levels } & & \\
\cline { 2 - 5 } & 1 & 2 & 3 & 4 \\
\hline Catalyst amount (g) & 0.2 & 0.4 & 0.6 & 0.8 \\
Dye concentration $\left(\mathrm{mg} \mathrm{L}^{-1}\right)$ & 10 & 20 & 30 & 40 \\
$\mathrm{pH}$ & 4 & 5.5 & 7 & 8.5 \\
Time (s) & 40 & 80 & 120 & 160 \\
\hline
\end{tabular}

the $\mathrm{S} / \mathrm{N}$ ratio is the decibel $(\mathrm{dB})$. The $\mathrm{S} / \mathrm{N}$ ratio is defined as:

$\frac{S}{N}=\frac{-10 \log \left(1 / y_{1}^{2}+1 / y_{2}^{2}+1 / y_{3}^{2}+\cdots+1 / y_{n}^{2}\right)}{n}$

where $y_{i}$ is the characteristic property, and $n$ is the replication number of the experiment (Kim et al. 2004).

\section{Batch decolorization process}

We analyzed the efficacy of NZVI particles on AG-25 dye removal. For this purpose, $0.2-0.8 \mathrm{~g}$ of catalyst was added to $25 \mathrm{~mL}$ of the dye solution in $100-\mathrm{mL}$ beakers. The $\mathrm{pH}$ of the sample solution was adjusted in the range of 4-8 using $\mathrm{HCl}$ and $\mathrm{NaOH}$ solution. The solution was stirred in the beakers using a magnetic stirrer at $200 \mathrm{rpm}$. To determine the remaining concentration and to calculate the percentage of AG-25 dye removal, the absorbance of solution was read at the wavelength of maximum dye using a UV-Vis spectrophotometer. All experiments were performed at ambient temperature. Each experiment was repeated three times, the mean values of each experiment were used as the final results in the calculations. In these experiments, Eq. (3) was used to determine the percentage of dye removal:

Dye removal $(\%)=\frac{c_{\mathrm{o}}-c_{\mathrm{e}}}{c_{\mathrm{o}}} \times 100$

where $C_{\mathrm{o}}\left(\mathrm{mg} \mathrm{L}^{-1}\right)$ is the initial concentration and $C_{\mathrm{e}}(\mathrm{mg}$ $\mathrm{L}^{-1}$ ) is the equilibrium concentration of the dye.

\section{Results and discussion}

\section{Characterization of the NZVI particles}

Scanning electron microscopy images will contribute to surface examination of the materials. To this end, SEM images were taken of the sample (Fig. 1). According to Fig. 1, the synthesized iron nanoparticles have almost identical morphology, being spherical and superficially

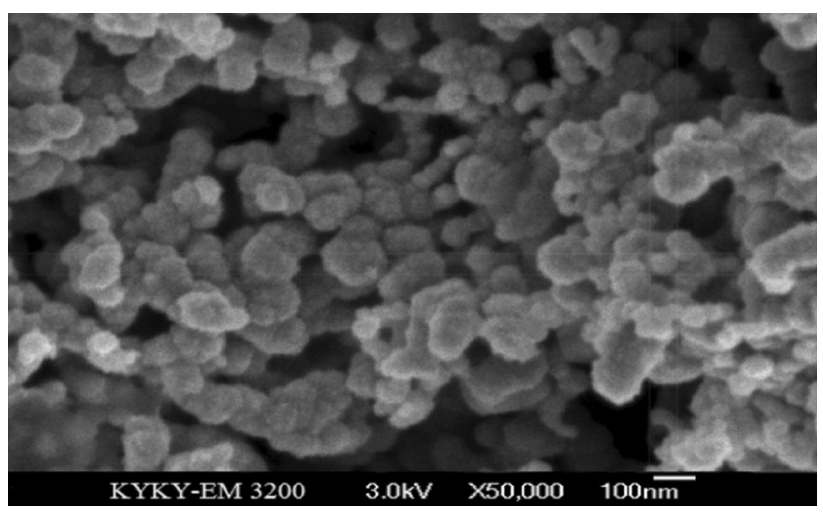

Fig. 1 Scanning electron microscopy image of nanoscale zero-valent iron (NZVI) particles

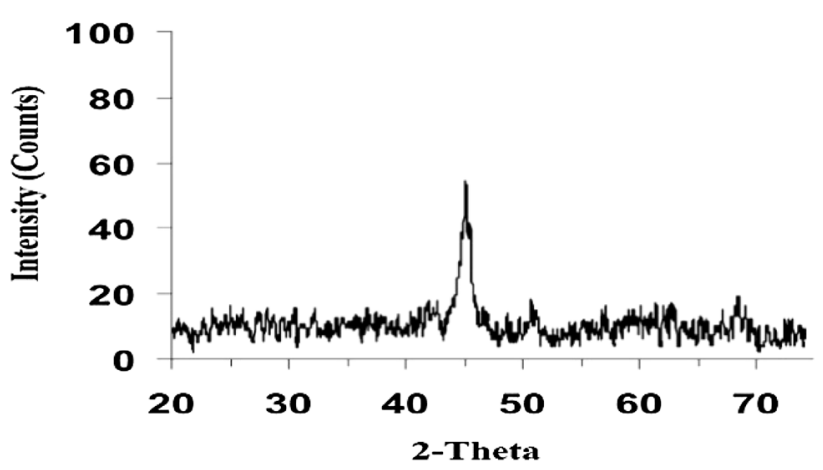

Fig. 2 X-ray diffraction pattern of NZVI particles

porous. The XRD patterns are shown in Fig. 2. The XRD analysis revealed the presence of NZVI as the main phase of the samples $\left(2 \theta=44.8^{\circ}\right)$.

\section{Determination of optimal conditions using the Taguchi method}

The experimental results and the S/N ratio for dye removal calculated using Eq. (2) are shown in Table 3, and the mean $\mathrm{S} / \mathrm{N}$ ratio for each level of the variables is shown in Table 4. In Table 4, the importance of each of the variables is specified for AG-25 dye removal. Dye concentration has the first and largest effect on the process of dye removal, followed by $\mathrm{pH}$, catalyst amount and finally by time as the fourth independent variable affecting for the percentage of dye removal.

The $\mathrm{S} / \mathrm{N}$ response graph for removal of AG-25 solution is shown in Fig. 3. The variance analysis was conducted to show the effect of each variable on the final result (Taguchi 1987). The results of the analysis of variance are shown in Table 5. Based on the results of variance analysis, initial dye concentration and $\mathrm{pH}$ are the most important variables in eliminating AG-25 dye, respectively. The degree of freedom for each factor is 3 and the total degree of freedom is 15 . 
Table 3 Experimental results for percentage of Acid Green 25 dye removal

\begin{tabular}{lllllll}
\hline Run & Catalyst amount $(\mathrm{g})$ & Dye concentration $\left(\mathrm{mg} \mathrm{L}^{-1}\right)$ & $\mathrm{pH}$ & Time $(\mathrm{s})$ & Dye removal $(\%)$ & S/N ratio \\
\hline 1 & 1 & 1 & 1 & 1 & 53.74 & 28.2758 \\
2 & 1 & 2 & 2 & 2 & 83.35 & 37.9525 \\
3 & 1 & 3 & 3 & 3 & 93.20 & 39.2665 \\
4 & 1 & 4 & 4 & 4 & 65.99 & 36.5215 \\
5 & 2 & 1 & 2 & 3 & 51.92 & 25.6454 \\
6 & 2 & 2 & 1 & 4 & 76.71 & 39.9565 \\
7 & 2 & 3 & 4 & 1 & 64.03 & 36.6502 \\
8 & 2 & 4 & 3 & 2 & 95.18 & 41.0252 \\
9 & 3 & 1 & 3 & 4 & 87.48 & 40.8245 \\
10 & 3 & 2 & 4 & 3 & 50.41 & 21.7904 \\
11 & 3 & 3 & 1 & 2 & 63.45 & 39.4626 \\
12 & 3 & 4 & 2 & 1 & 65.73 & 37.6163 \\
13 & 4 & 1 & 4 & 2 & 74.68 & 39.3697 \\
14 & 4 & 2 & 3 & 1 & 75.49 & 38.5884 \\
15 & 4 & 3 & 2 & 4 & 68.51 & 39.2758 \\
16 & 4 & 4 & 1 & 3 & 73.83 & 39.7354 \\
\hline
\end{tabular}

$S / N$ ratio signal to noise ratio

\begin{tabular}{|c|c|c|c|c|c|}
\hline \multirow[t]{2}{*}{ Variables } & \multicolumn{5}{|c|}{ Mean $\mathrm{S} / \mathrm{N}$ ratio } \\
\hline & Level 1 & Level 2 & Level 3 & Level 4 & Rank \\
\hline Catalyst amount (g) & 77.32 & 83.15 & 88.75 & 91.17 & 3 \\
\hline Dye concentration $\left(\mathrm{mg} \mathrm{L}^{-1}\right)$ & 94.75 & 87.63 & 81.75 & 77.88 & 1 \\
\hline $\mathrm{pH}$ & 95.63 & 85.75 & 80.92 & 78.75 & 2 \\
\hline Time (s) & 80.25 & 84.38 & 88.25 & 89.13 & 4 \\
\hline
\end{tabular}
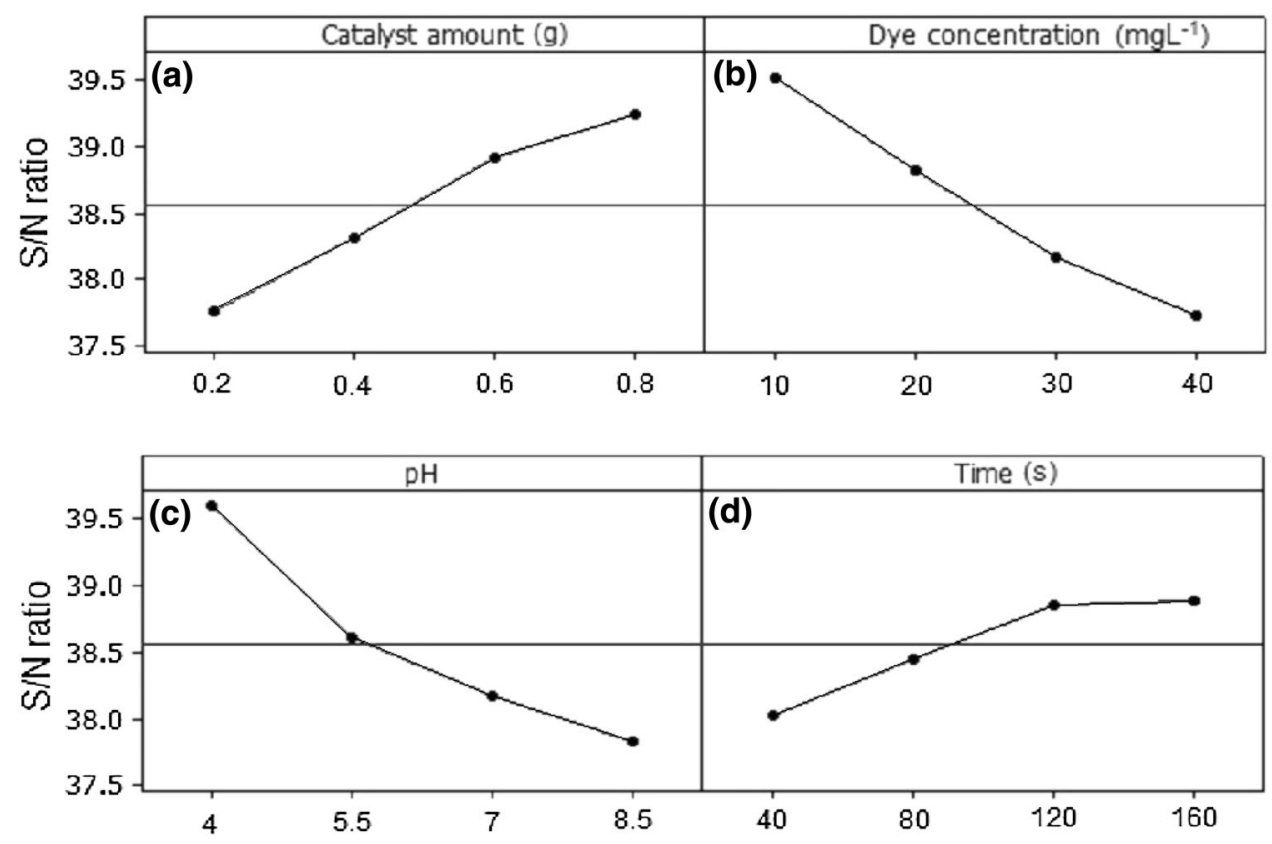
Table 5 Analysis of variance

\begin{tabular}{lcrl}
\hline Variables & Sum of square & $d f$ & Variance \\
\hline Catalyst amount $(\mathrm{g})$ & 1839.591 & 3 & 613.196 \\
Dye concentration $\left(\mathrm{mg} \mathrm{L}^{-1}\right)$ & 3971.043 & 3 & 1323.681 \\
$\mathrm{pH}$ & 2568.568 & 3 & 856.189 \\
Time (s) & 979.846 & 3 & 326.615 \\
Error & 84.395 & 3 & 28.131 \\
Total & 9443.443 & 15 & -
\end{tabular}

\section{Effect of catalyst amount}

The amount of catalyst is an important parameter affecting the process of dye removal. As shown in Fig. 3a, the percentage of AG-25 dye removal was dependent on catalyst amount and sharply increased with increasing catalyst amount from 0.2 to $0.6 \mathrm{~g}$. However, there is no significant increase in the efficiency of dye removal when the amount of catalyst surpassed $0.6-0.8 \mathrm{~g}$. The most likely explanation for this result is that the sites of adsorption remained unsaturated during the process of adsorption, with the number of sites available for the site of adsorption increasing with increasing the catalyst amount. The percentage of dye removal is increased by increasing the amount of NZVI particles. The increase in efficiency could be obtained due to increasing the active surface available for chromogenic material (Dutta et al. 2016; Shojaei et al. 2017).

\section{Effect of dye concentration}

Dye concentration also provides a significant driving force to overcome the total resistance of transferring color mass between liquid and solid phases. We tested the effect of different amounts of dye $\left(10-40 \mathrm{mg} \mathrm{L}^{-1}\right)$. The results show that there was a decrease in the process efficiency with increasing concentration of the dye from 10 to $40 \mathrm{mg}$ $\mathrm{L}$ (Fig. 3b), with the maximum amount of discoloration obtained at a dye concentration of $10 \mathrm{mg} \mathrm{L}^{-1}$. Adsorption was considerably decreased with increasing dye concentration due to saturation of the active sites of the catalyst and a parallel reduction in the adsorption surface available, resulting from the consistency of catalyst amount against an increasing amount of chromogenic material (Chompuchan et al. 2010; Li et al. 2006). Reductions in the concentration of pollutants in the environment provide molecules of absorbed material with a greater opportunity to react with adsorption sites; thus, the adsorption rate is increased in these conditions. Based on these results, we suggest that dilution is one method to increase the percentage of dye removal in polluted sewage (Vadivelan and Kumar 2005; Bulut and Aydın 2006).

\section{Effect of pH}

$\mathrm{pH}$ is a factor which impacts the process of adsorption by affecting the structure of the pollutants/color and catalyst (Shu et al. 2009; Almeelbi and Bezbaruah 2012). As shown in Fig. 3c) when the $\mathrm{pH}$ of a solution is acidic ( $\mathrm{pH} 4)$, dye removal is very high but the discoloration is reduced by increasing the $\mathrm{pH}$ up to 8.5 . Thus, an acidic $\mathrm{pH}$ is effective in achieving maximum dye removal. At an acidic $\mathrm{pH}$, the surface of metallic iron is constantly kept clean so that the iron is constantly revived (Chamarro et al. 2001). Deposits of $\mathrm{Fe}(\mathrm{OH})_{3}$ cannot be formed at acidic $\mathrm{pH}$, which in turn will increase the production of free electrons and prevent the creation of iron powder deposits. At an alkaline $\mathrm{pH}$, $\mathrm{Fe}^{2+}$ is also converted into $\mathrm{Fe}^{3+}$ and removed from the catalytic cycle in the form of $\mathrm{Fe}(\mathrm{OH})_{3}$ (Önal et al. 2006; Ravikumar et al. 2006; Sun et al. 2006).

\section{Effect of contact time}

The results of the effect of contact time (40-160 s) are shown in Fig. 3d. According to these results, dye removal efficiency is significantly increased with increasing contact time. Both superficial adsorption capacity and dye removal percentage by the catalyst increased rapidly during the initial stages, followed by a slower pace, and in accordance with the time, the upward trend was paced to achieve equilibrium over a period of about $120 \mathrm{~s}$. On the other hand, some degree of the saturated adsorption and penetration of pollutants into the pores of the catalyst will require more time due to the increase in contact time (Cao et al. 1999; Fan et al. 2009; Saha 2010; Satapanajaru et al. 2011).

\section{Optimization}

Any of these variables tested can be chosen to increase dye removal efficiency, as they have a large effect on the output response. Optimum conditions of the removal of AG-25 dye using NZVI particles are shown in Table 6. Optimization of the method resulted in dye removal values of $>93 \%$, which indicates the correct application of the Taguchi method and $\mathrm{L}_{16}$ model in designing the removal process of AG-25 dye by using NZVI particles.

The optimal parameters are a catalyst amount at level 3 $(0.6 \mathrm{~g})$, dye concentration at level $2\left(20 \mathrm{mg} \mathrm{L}^{-1}\right), \mathrm{pH}$ at level 1 (4) and time at level 3 (120 s). 
Table 6 Optimum conditions derived by Taguchi method for removal of Acid Green 25 dye

\begin{tabular}{llllll}
\hline \multirow{2}{*}{ Experiment } & \multicolumn{2}{l}{ Optimal conditions } & & & \\
\cline { 2 - 6 } & Catalyst amount $(\mathrm{g})$ & Dye concentration $\left(\mathrm{mg} \mathrm{L}^{-1}\right)$ & $\mathrm{pH}$ & Time $(\mathrm{s})$ & Dye removal (\%) \\
\hline 1 & 3 & 2 & 1 & 3 & 95.46 \\
2 & 3 & 2 & 1 & 3 & 93.35 \\
3 & 3 & 2 & 1 & 3 & 96.82 \\
\hline
\end{tabular}

\section{Conclusion}

The results of these studies show that NZVI particles prepared by the synthesis method were an efficient catalyst the removal of AG-25 dye from solution. The use of the Taguchi method involving the L16 model for optimization of process variables was studied. The removal of AG-25 dye was dependent on the catalyst amount, dye concentration, $\mathrm{pH}$ and time. Each variable was analyzed at four levels, with the results showing that removal percentage increased with increasing catalyst amount and time and that there was an opposite effect with increasing dye concentration and $\mathrm{pH}$. The results of the Taguchi method showed that dye concentration had the most important impact on the process of dye removal, followed by $\mathrm{pH}$, catalyst amount, and time in decreasing order of impact. In total, $96.82 \%$ of the AG-25 dye was removed under the optimized optimal conditions (catalyst amount $0.6 \mathrm{~g}$, dye concentration $20 \mathrm{mg} \mathrm{L}^{-1}, \mathrm{pH} 4$, time $120 \mathrm{~s}$ ), which shows that the process has the high capacity to remove AG-25 dye from the aquatic environment. Thus we consider this process to be a suitable option to remove AG- 25 dye from solution.

Acknowledgements The authors would like to acknowledge the financial support and use of instruments provided by the Payam-eNoor University, Iran.

\section{Compliance with ethical standards}

Conflict of interest The authors declare that they have no competing interests.

\section{References}

Akcil A, Erust C, Ozdemiroglu S, Fonti V, Beolchini F (2015) A review of approaches and techniques used in aquatic contaminated sediments: metal removal and stabilization by chemical and biotechnological processes. J Clean Prod 86:24-36

Almeelbi T, Bezbaruah A (2012) Aqueous phosphate removal using nanoscale zero-valent iron. J Nanopart Res 14(7):900

Alpat SK, Özbayrak Ö, Alpat Ş, Akçay H (2008) The adsorption kinetics and removal of cationic dye, Toluidine Blue $\mathrm{O}$, from aqueous solution with Turkish zeolite. J Hazard Mater 151(1):213-220

Bigg T, Judd SJ (2000) Zero-valent iron for water treatment. Environ Technol 21(6):661-670
Bulut Y, Aydin H (2006) A kinetics and thermodynamics study of methylene blue adsorption on wheat shells. Desalination 194(1-3):259-267

Cao JS, Wei LP, Huang QG, Wang LS, Han SK (1999) Reducing degradation of azo dye by zero-valent iron in aqueous solution. Chemosphere 38:565-571

Chamarro E, Marco A, Esplugas S (2001) Use of Fenton reagent to improve organic chemical biodegradability. Water Res 35(4):1047-1051

Chompuchan C, Satapanajaru T, Suntornchot P, Pengthamkeerati P (2010) Decolorization of Reactive Black 5 and Reactive Red 198 using nanoscale zerovalent iron. Int $\mathbf{J}$ Environ Sci Eng 2(3): $123-127$

Dutta S, Saha R, Kalita H, Bezbaruah AN (2016) Rapid reductive degradation of azo and anthraquinone dyes by nanoscale zerovalent iron. Environ Technol Innov 5:176-187

Fan J, Guo Y, Wang J, Fan M (2009) Rapid decolorization of azo dye methyl orange in aqueous solution by nanoscale zerovalent iron particles. J Hazard Mater 166(2):904-910

Glavee GN, Klabunde KJ, Sorensen CM, Hadjipanayis GC (1995) Chemistry of borohydride reduction of iron (II) and iron (III) ions in aqueous and nonaqueous media. Formation of nanoscale $\mathrm{Fe}, \mathrm{FeB}$, and $\mathrm{Fe} 2 \mathrm{~B}$ powders. Inorg Chem 34:28

Gök Ö, Özcan AS, Özcan A (2010) Adsorption behavior of a textile dye of Reactive Blue 19 from aqueous solutions onto modified bentonite. Appl Surf Sci 256(17):5439-5443

Han R, Wang Y, Sun Q, Wang L, Song J, He X, Dou C (2010) Malachite green adsorption onto natural zeolite and reuse by microwave irradiation. J Hazard Mater 175(1):1056-1061

Kim ST, Park MS, Kim HM (2004) Systematic approach for the evaluation of the optimal fabrication conditions of a $\mathrm{H}_{2} \mathrm{~S}$ gas sensor with Taguchi method. Sens Actuators B Chem 102(2):253-260

Lewis DM (2014) Developments in the chemistry of reactive dyes and their application processes. Color Technol 130(6):382-412

Li XQ, Elliott DW, Zhang WX (2006) Zero-valent iron nanoparticles for abatement of environmental pollutants: materials and engineering aspects. Crit Rev Solid State Mater Sci 31(4):111-122

Mahanta D, Madras G, Radhakrishnan S, Patil S (2008) Adsorption of sulfonated dyes by polyaniline emeraldine salt and its kinetics. J Phys Chem B 112(33):10153-10157

Nalbant M, Gökkaya H, Sur G (2007) Application of Taguchi method in the optimization of cutting parameters for surface roughness in turning. Mater Des 28(4):1379-1385

Önal Y, Akmil-Başar C, Eren D, Sarıcı-Özdemir Ç, Depci T (2006) Adsorption kinetics of malachite green onto activated carbon prepared from Tunçbilek lignite. J Hazard Mater 128(2): $150-157$

Prado AG, Bolzon LB, Pedroso CP, Moura AO, Costa LL (2008) $\mathrm{Nb}_{2} \mathrm{O}_{5}$ as efficient and recyclable photocatalyst for indigo carmine degradation. Appl Catal B 82(3):219-224

Ravikumar K, Ramalingam S, Krishnan S, Balu K (2006) Application of response surface methodology to optimize the process variables for reactive red and acid brown dye removal using a novel adsorbent. Dyes Pigm 70(1):18-26 
Roy RK (2001) Design of experiments using the Taguchi approach: 16 steps to product and process improvement. Wiley, New York

Saha P (2010) Assessment on the removal of methylene blue dye using tamarind fruit shell as biosorbent. Water Air Soil Pollut 213(1-4):287-299

Satapanajaru T, Chompuchan C, Suntornchot P, Pengthamkeerati P (2011) Enhancing decolorization of Reactive Black 5 and Reactive Red 198 during nano zerovalent iron treatment. Desalination 266(1):218-230

Shojaei S, Shojaei S, Sasani M (2017) The efficiency of eliminating Direct Red 81 by Zero-valent Iron nanoparticles from aqueous solutions using response surface Model (RSM). Model Earth Syst Environ 3(1):27

Shu HY, Chang MC, Chang CC (2009) Integration of nanosized zerovalent iron particles addition with $\mathrm{UV} / \mathrm{H}_{2} \mathrm{O}_{2}$ process for purification of azo dye Acid Black 24 solution. J Hazard Mater 167(1):1178-1184

Solache-Ríos MJ, Villalva-Coyote R, Díaz-Nava MDC (2010) Sorption and desorption of remazol yellow by a Fe-zeolitic tuff. J Mex Chem Soc 54(1):59-68
Sun YP, Li XQ, Cao J, Zhang WX, Wang HP (2006) Characterization of zero-valent iron nanoparticles. Adv Coll Interface Sci 120(1):47-56

Taguchi G (1987) System of experimental design; engineering methods to optimize quality and minimize costs. Quality Resources, White Plains, NY

Taguchi G, Chowdhury S, Taguchi S (2000) Robust engineering. McGraw-Hill Professional, New York

Vadivelan V, Kumar KV (2005) Equilibrium, kinetics, mechanism, and process design for the sorption of methylene blue onto rice husk. J Colloid Interface Sci 286(1):90-100

Verma DK, Banik RM (2013) Decolorization of triphenylmethane dyes using immobilized fungal biomass. Int J Res 4:1-12

Yu S, Liu M, Ma M, Qi M, Lü Z, Gao C (2010) Impacts of membrane properties on reactive dye removal from dye/salt mixtures by asymmetric cellulose acetate and composite polyamide nanofiltration membranes. J Membr Sci 350(1):83-91 